\title{
MRI evaluation of extremity schwannoma characteristics
}

\section{Ekstremite şıvannoma karakteristiklerinin MRG ile değerlendirilmesi}

\author{
Ali Koc
}

University of Health Sciences, Kayseri Training and Research Hospital, Department of Radiology, Kayseri

Corresponding author:Ali Koç. University of Health Sciences, Kayseri Training and Research Hospital, Department of Radiology, Kayseri.

E-mail: radalikoc@gmail.com

Received/Accepted: February 22, 2018 / April 09, 2018

Conflict of interest: There is not a conflict of interest.

\section{SUMMARY}

Objective: To evaluate signal characteristics, soft tissue signs and contrast enhancement patterns of extremity schwannomas with Magnetic Resonance Imaging (MRI).

Method: The study was comprised of 16 patients with a pathological diagnosis of benign peripheral nerve sheath tumor (schwannoma) originated from different extremity regions. All patients had MRI exams. MRIs were evaluated for the signal characteristics, the presence of special signs described for soft tissue tumors, and contrast enhancement patterns of the lesions.

Results: Schwannomas were originated from median nerve $(n=7)$, radial nerve $(n=4)$, femoral nerve $(n=2)$, axillary nerve $(\mathrm{n}=1)$, common peroneal nerve $(\mathrm{n}=1)$, and posterior tibial nerve $(\mathrm{n}=1)$. Four types of signal characteristic were described according to the T1W and T2W MR images. All schwannomas $(n=16)$ had split fat sign, 15 of them showed enteringexiting nerve sign, 10 had target sign and 10 had fascicular sign. On contrast enhanced images, 12 of the cases showed peripheral heterogenous enhancement with centrally unenhanced curvilinear areas. Four cases had homogenous contrast enhancement.

Conclusions: Most of the extremity schwannomas have diagnostic signal characteristics, soft tissue signs and contrast enhancement patterns on MRI. Preoperative MRI diagnosis of these lesions can reduce the necessity of biopsy and prevent the possibility of nerve fascicle injury.

Keywords: Extremity; magnetic resonance imaging; Schwannoma

\section{ÖZET}

Amaç: Ekstremite şıvannomalarının sinyal karakteristiklerinin, yumuşak doku işaretlerinin ve kontrast tutulum paternlerinin Manyetik Rezonans Görüntüleme ile değerlendirilmesi.

Yöntem: Çalıșma grubu, değișik ekstremite bölgelerinden kaynaklı, patolojik tanısı periferik sinir k1lıf tümörü (şıvannoma) olan 16 hastadan olușturuldu. Bütün hastaların MR incelemeleri mevcuttu. MR incelemeleri; lezyonların sinyal karakteristikleri, yumuşak doku tümörleri için tanımlanmış bazı işaretler ve kontrast tutulum paternleri yönünden değerlendirildi.

Bulgular: Sivannomalar; medyan sinir $(n=7)$, radyal $\operatorname{sinir}(n=4)$, femoral sinir $(n=2)$, aksiller sinir $(n=1)$, ortak peroneal $\operatorname{sinir}(\mathrm{n}=1)$, ve posterior tibial sinir (n=1) orijinli idi. T1 ve T2 ağıllıklı MR görüntülere göre; lezyonlara ait dört farklı sinyal karakteristiği tanımlandı. Bütün şıvannomalarda ayrışmış yağ işareti, 15'inde giren-çıkan sinir işareti. 10'unda hedef işareti ve 10'unda fasiküler işaret mevcuttu. Kontrastlı görüntülerde, olguların 12'sinde kontrast tutulumu göstermeyen santral alana eşlik eden çevresel ağılılıklı heterojen kontrastlanma saptandı. Dört olguda ise homojen kontrast tutulumu mevcuttu.

Sonuç: Ekstremite şıvannomalarının çoğunluğu, MR görüntülemede kendine ait sinyal karakteristikleri, yumușak doku işaretleri ve kontrast tutulum paterni gösterir. Bu lezyonların cerrahi öncesi MR görüntüleme ile tanı alması, gereksiz biyopsi ișlemlerini ve ilișkili olarak olası sinir fasikül hasarını önler.

Anahtar sözcükler: Ekstremite; Manyetik Rezonans Görüntüleme; Şıvannoma. 



\section{INTRODUCTION}

Schwannomas are benign peripheral nerve sheath tumors. They represent approximately $5 \%$ of all soft-tissue tumors. Most of the cases occur sporadically, but some may be seen in association with genetic disorders such as neurofibromatosis. Schwannomas are the most common solitary tumor of the peripheral nerve. They typically present as a slow-growing, round mass with paresthesias of the associated nerve distribution. In the upper extremities, flexor surface is the most common location due to the presence of large nerves ${ }^{1}$.

Schwannomas demonstrate typical MRI features of T1 iso-to-hypointensity, T2 hyperintensity, and postcontrast enhancement. Heterogeneous signal intensity and postcontrast enhancement are suggestive of internal hemorrhage and myxoid/cystic changes. There are additional imaging and pathological features which suggest the diagnosis of schwannomas. The entering and exiting nerve sign describes the presence of a peripheral nerve coursing in and out of the mass. The target sign consists of low/intermediate T2 signal centrally (fibrous tissue), with high $\mathrm{T} 2$ signal peripherally (myxoid tissue). The fascicular sign represents multiple ring-like structures, corresponding to fascicular bundles ${ }^{1}$. A secondary sign that may suggest a neurogenic neoplasm is muscle atrophy within the nerve distribution ${ }^{2}$.

Distinguishing benign schwannomas from malignant soft-tissue tumors can be challenging and often may not be possible. Features that favor malignant transformation include ill-defined margins and larger size $(>5 \mathrm{~cm})^{3}$.

Features that should favor schwannoma over malignant soft-tissue tumors include the split fat sign (rim of fat surrounding the tumor), the bright rim sign (high T2 signal at the periphery of the mass), absence of lobular shape (defined as <2 or more deep lobulations), lack of extensive peritumoral edema (extensive defined as $>18 \mathrm{~mm}$ ), and a defined capsule ${ }^{10}$. These findings are reliable for schwannoma if two or more coexist ${ }^{4}$.

In this study, we aimed to evaluate signal characteristics and contrast enhancement patterns of extremity schwannomas with MRI.

\section{MATERIAL AND METHODS}

MRI exams of 16 patients with a pathological diagnosis of benign peripheral nerve sheath tumor (schwannoma) of different extremity regions that operated at different medical centers were evaluated. Five of the patients were male and 11 of them were female. The average age of patients was
42.2 years ranging from 14 to 69 . All patients had MRIs, archieved in PACS (Picture Archieving and Communication System) between the years of 2009-2017 in the radiology department of our hospital. Extremity MRI protocol was composed of sequences as: sagittal and coronal proton-density weighted (PDW) Fat Sat (TR: 1700-2200/TE: 40$48 \mathrm{msn}$; slice thickness: $3 \mathrm{~mm}$ ), T2 weighted (T2W) Fast Spin Echo (FSE) (TR: 3600-3900/TE: 86-98 msn; slice thickness: $3 \mathrm{~mm}$ ), coronal $\mathrm{T} 1$ weighted (T1W) FSE (TR: 450-495/TE: 10-14 msn; slice thickness: $3 \mathrm{~mm}$ ), and post-contrast axial and coronal T1W FSE Fat Sat. All MRI exams were evaluated for the size and localization of tumor, signal characteristics on $\mathrm{T} 1 \mathrm{~W}, \mathrm{~T} 2 \mathrm{~W}$, PDW sequences, the presence of soft tissue tumor signs and contrast enhancement patterns of the lesions.

\section{RESULTS}

Locations of 16 tumoral lesions were found as follows; five of them in the arm, four in the forearm, two in the cruris, two in the thigh, one in the elbow, one in the wrist and one in the proximal phalanx of the hand. The tumor size was ranged from $11 \times 8 \mathrm{~mm}$ to $78 \times 33 \mathrm{~mm}$. All of the lesions had smooth, well-defined borders with an ovoid shape. Peripheral nerves that tumors originated were as median nerve $(n=7)$, radial nerve $(n=4)$, femoral nerve $(n=2)$, axillary nerve $(n=1)$, common peroneal nerve $(n=1)$, and posterior tibial nerve $(n=1)$. Only three of the cases originated from radial nerve were situated at the extensor side of the extremity, while rest of them were at the flexor side. On MR images, all schwannomas showed the split fat sign, 15 of them had entering-exiting nerve sign, 10 had target sign and 10 had fascicular sign (Figure 1a-c). Four types of signal characteristic were identified according to the $\mathrm{T} 1 \mathrm{~W}$ and $\mathrm{T} 2 \mathrm{~W}$ images (Figure 2a,b). In five cases, lesions were seen as isointense on $\mathrm{T} 1 \mathrm{~W}$ images related to the muscle tissue and hyperintense on $\mathrm{T} 2 \mathrm{~W}$ images with central hypointense reticulonodular components. In five cases, lesions were seen as isointense on $\mathrm{T} 1 \mathrm{~W}$ and hyperintense on $\mathrm{T} 2 \mathrm{~W}$ with central hypointense reticulonodular components on both sequences. In three cases, lesions were isointense on $\mathrm{T} 1 \mathrm{~W}$ and hyperintense on $\mathrm{T} 2 \mathrm{~W}$. In two cases, lesions were isointense on $\mathrm{T} 1 \mathrm{~W}$ and hyperintense on $\mathrm{T} 2 \mathrm{~W}$ with central isointensity. On contrast enhanced images, 12 of the cases showed peripheral heterogenous enhancement with centrally unenhanced curvilinear areas (Figure $3 a, b)$. Four cases had homogenous contrast enhancement. 


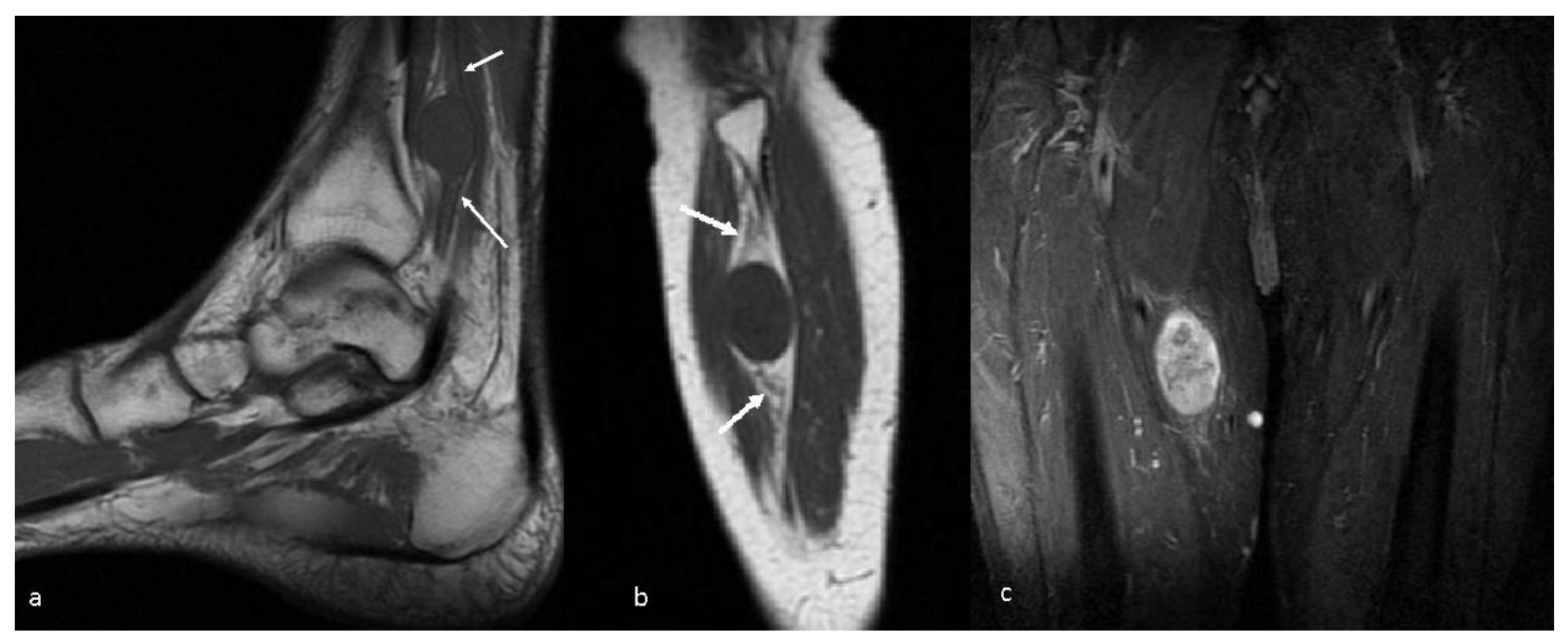

Figure 1. Sagittal (a) and coronal (b) T1W images show a peroneal nerve schwannoma with entering-exiting nerve sign (arrows) and split fat sign (arrows). (c) Coronal T2W Fat Sat image shows a femoral nerve schwannoma with target and fascicular signs.

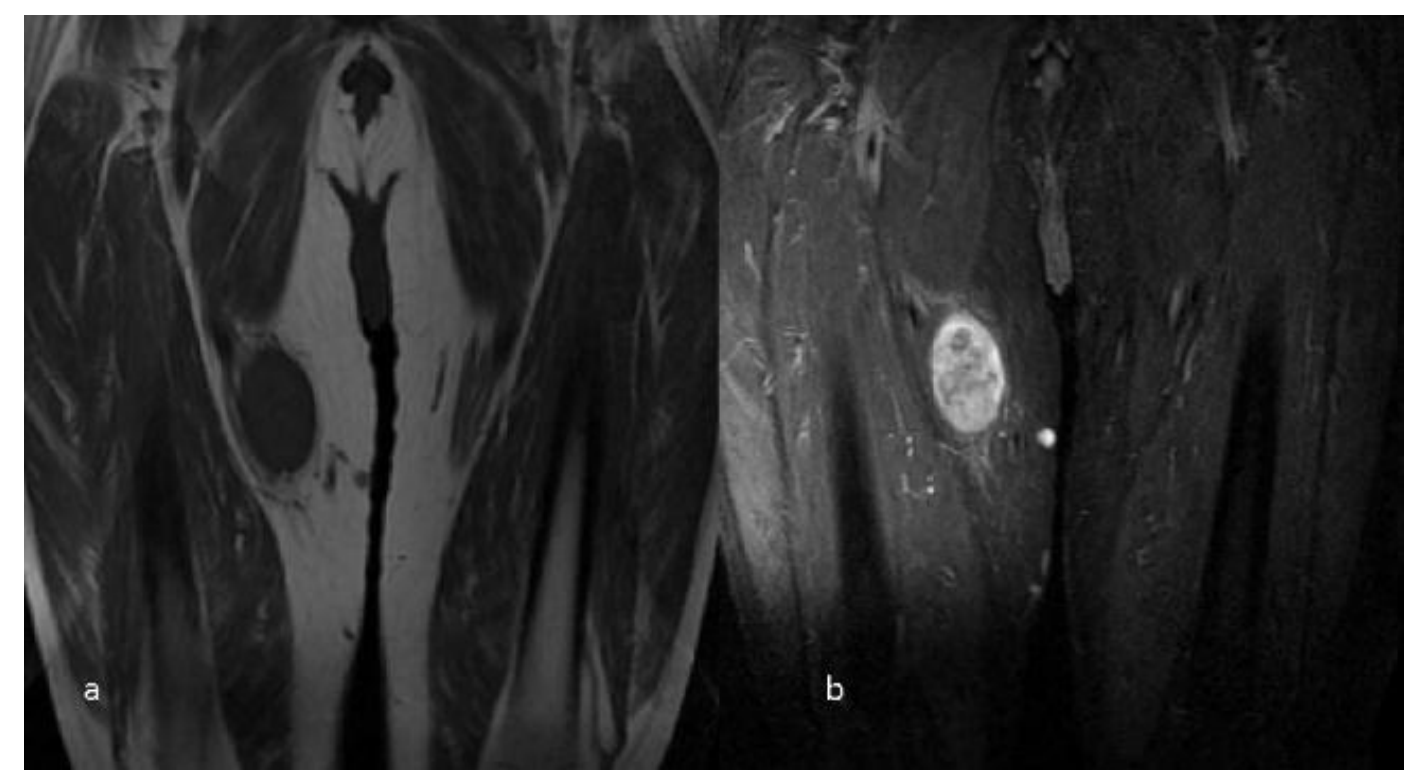

Figure 2. Coronal T1W (a) and T2W STIR (b) images show a femoral nerve schwannoma with a signal characteristic as hypointense curvilinear components centrally and peripheral hyperintense areas on $\mathrm{T} 2 \mathrm{~W}$, and isointense on $\mathrm{T} 1 \mathrm{~W}$. 


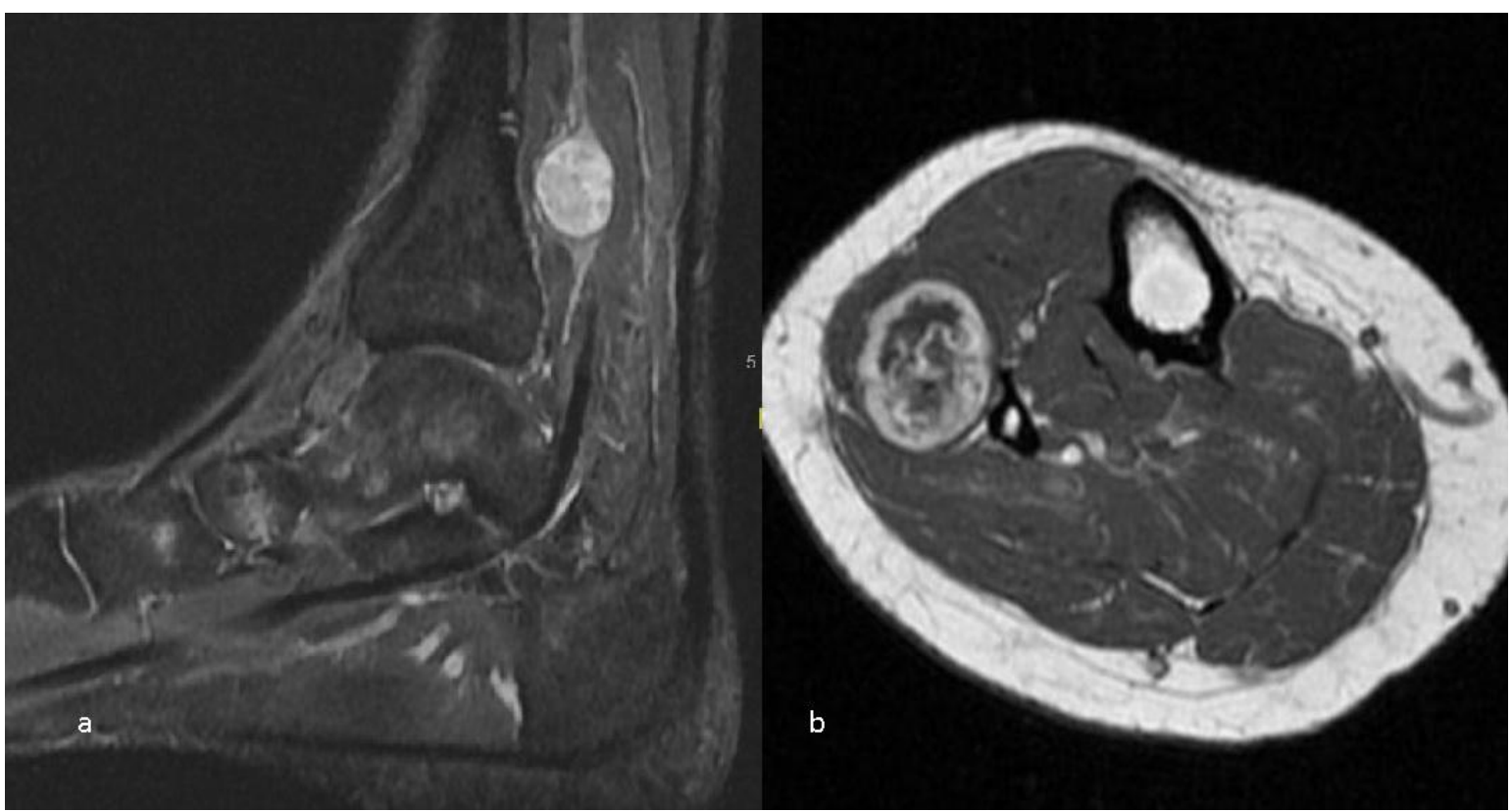

Figure 3. Coronal T2W STIR (a) and contrast enhanced axial T1W (b) images show a crural schwannoma. Lesion had heterogenous contrast enhancement with unenhanced central areas.

\section{DISCUSSION}

The diagnosis of a soft tissue tumour is usually confirmed by open biopsy, which is not recommend when a peripheral nerve sheath tumour is considered due to the risk of nerve injury. Ultrasound-guided needle biopsy seems to be less invasive but the possibility of provoking a nerve fascicle injury is still present. Among many different diagnostic methods, MRI is considered the most helpful in confirming the diagnosis preoperatively ${ }^{5,6}$. In our study, preoperative USGguided biopsy was not planned for any case while all cases had a diagnosis of schwannoma according to the MRI exams.

MRI can demonstrate the tumour origin and its anatomical relationship to the surrounding structures. The MRI aspect of a schwannoma is a homogeneous mass, with a middle-low intensity signal at SE T1-weighted sequences, whereas at T2-weighted sequences it shows a high signal. An ancient schwannoma produces a different image, because of its low-density signal areas, which are caused by hyalin and fibrosis degeneration ${ }^{7,8}$. In the present study, lesions had four different signal characteristics on T1W and T2W images. Most of them $(n=10)$ had hypointense reticulonodularcurvilinear components centrally and evident hyperintensity peripherally on T2W with isointensity on T1W images. All of the cases had split fat sign. Entering and exiting nerve sign was not seen in only one case with a dimension of $11 \times 8$ $\mathrm{mm}$.
After contrast infusion, schwannomas show a large enhancement (like the neurofibromas), whereas in case of necrotic or cystic areas, or if there is a "target sign", the resulting image is different. The "target sign" in $50 \%$ of cases is due to a central low-intensity signal (fibrous component) and a peripheral high-intensity signal (myxedematous component). It has been reported that MRI does not seem to be always adequate to distinguish between schwannomas and neurofibromas ${ }^{5}$. In this study, 10 cases had target sign. Twelve cases had heterogenous contrast enhancement with unenhanced central curvilinear areas and, four cases showed homogenous enhancement. Schwannomas with central hypointensity on T2W images had heterogenous contrast enhancement, while isointense lesions showed homogenous enhancement.

\section{CONCLUSION}

Extra-craniospinal schwannomas have diagnostic characteristics on MRI and careful interpretation of MR images will allow to diagnose these tumors correctly in most cases and can reduce the preoperative biopsy requirement.

\section{REFERENCES}

1. Forthman CL, Blazar PE. Nerve tumors of the hand and upper extremity. Hand Clin 2004;20:233-242.

2. Murphey MD, Smith WS, Smith SE, Kransdorf MJ, Temple HT. From the archives of the AFIP. Imaging of musculoskeletal 
neurogenic tumors: Radiologic-pathologic correlation. Radiographics 1999;19:12531280.

3. Ducatman BS, Scheithauer BW, Piepgras DG, Reiman HM, Ilstrup DM. Malignant peripheral nerve sheath tumors. A clinicopathologic study of 120 cases. Cancer 1986;57:2006-2021.

4. Zhang Z, Deng L, Ding L, Meng Q. MR imaging differentiation of malignant soft tissue tumors from peripheral schwannomas with large size and heterogeneous signal intensity. Eur J Radiol 2015;84:940-946.

5. Hems TEJ, Burge PD, Wilson DJ. The role of magnetic resonance imaging in the management of peripheral nerve tumors. J Hand Surg 1997;22:57-60.

6. Park MJ, Seo KN, Kang HJ. Neurological deficit after surgical enucleation of schwannomasof the upper limb. J Bone Joint Surg Br 2009;91:1482-1486.

7. Isobe $\mathrm{K}$, Tominaga $\mathrm{S}$, Tsutomu A, Hiroyuki $\mathrm{K}$. Imaging of ancient schwannoma. Am J Radiol 2004;183:331-336.

8. Adani R, Tarallo L, Mugnai, Colopi S. Schwannomas of the upper extremity: analysis of 34 cases. Acta Neurochir 2014;156:2325-2330. 